\title{
The Development of Guidance and Counseling Management Model Based on Sumang Gayo
}

\author{
Hendri Putra \\ Postgradute Program, Department of Educational Administration \\ Universitas Negeri Medan \\ Medan, Indonesian \\ Corresponding email : hendri_putra2378@yahoo.co.id \\ Rosmala Dewi \\ Postgradute Program, Department of Educational Administration \\ Universitas Negeri Medan \\ Medan, Indonesian \\ Ibnu Hajar \\ Postgradute Program, Department of Educational Administration \\ Universitas Negeri Medan \\ Medan, Indonesian
}

\begin{abstract}
This research integrates Sumang Gayo values into guidance and management model. Sumang gayo are the valuaes that govern the behavior the Gayo highland community. Therefore, the purpose of this research is to develop a guidance and counseling management model on based of sumang gayo. The method used in this research using Research and Development (R\&D) approach, with the steps: research and information collecting, planning, develop Preliminary form of roduct, preliminary field test, main product revision, main field testing, operational product revision, operational field testing, final product revision, dissemination and implementation. The development of guidance and counseling management model on based Sumang Gayo is rated by 14 respondents. Assessment of 3 instructors counseling and counseling district of Central Aceh are very appropriate $(90 \%)$, assessment of 3 headmaster are very appropriate $(90 \%)$, assessment of 2 supervisors guidance and counseling are very appropriate $(100 \%)$, assessment of 3 senior teacher are very appropriate $(\mathbf{9 0 \%})$, assessment of 3 management board of teacher guidanse and counseling District of Central Aceh are very appropriate $(90 \%)$.the purpose of this research is to produce prototype of guidance and counseling management model based on sumang gayo wich done with external validation. The result of external validation in this research indicates that the development of guidance and counseling management model based sumang gayo is veri feasible to be used.
\end{abstract}

Keywords-Guidance and Counseling Management, Based Sumang Gayo.

\section{INTRODUCTION}

Counselors should be able to conduct counseling and guidance management. Permendikbud Number : 111 in the year of 2014 becomes reference in the implementation of management guidance and counseling related to planning, organizing, actuating, leading and controlling. Guidance and counseling management is an effort used to utilize all components or resources (personnel, funds, facilities) and information systems, guidance and counseling data sets to provide guidance and counseling services in order to achieve the stated objectives. [1]

Guidance and counseling management as an important part of character education. Counseling and counseling services are considered effective enough to assist students in developing cognitive, affective and psychomotor aspects [2].

Psychological development of students should lead to the formation of personal behaviors that refer to religion, science and technology, customary law and culture.Laws of the Government of Indonesia No.12 of 1954 article 3 and 4, Law no. 2 of 1989, Law No.20 of 2003, which is about democratic citizens, virtuous noble character, responsible, noble and democratic morale [3]

Character education is not only taught in subjects, but it needs clear, structured and systematic implementation of each subject through the design of instructional strategies used by teachers. Good cooperation with various parties strongly supports the implementation of character education in schools.

The people of Gayo in Central Aceh District makes sumang gayo to control individual and community behavior. At school sumang gayo aims to educate students into character generation. There are 4 characters in sumang gayo : thinking and positive attitude (sumang penengonen), effective communication (sumang perceraken), social ethics (sumang pelangkahen), attitude, courtesy (sumang kenunulen). Sumang gayo is a representation of the view of life, civilization, thinking that grows and develops in society. Sumang gayo is Gayo culture that must be preserved. Sumang gayo organizes one's behavior, virtuous noble character, responsible, noble character [4]. 
Sumang gayo is a culture that must be preserved, because sumang gayo set the values of life in Gayo society to behave, ethics, and morals are commendable. Sumang gayo in the community in Gayo Highlands is the custom which regulates the social interaction in interacting socially [5] So, sumang gayo needs to be developed into a school curriculum section [6].

Gayo culture such as "Sumang Gayo" began to disappear in the Gayo area, to preserve the culture needs a breakthrough in the field of education so that the culture remains a part of the character of the next generation, the values of sumang gayo need to be integrated into the management of guidance and counseling in schools [7]. Guidance and counseling programs based on sumang gayo conducted in schools must be systematized. So, school counselors should have good competence. The competence is to plan the program, implement the program and evaluate the guidance and counseling program based on sumang gayo. All this is done to develop the psychological aspects of students are affective, cognitive and psychomotor. This study aims to produce a guidance and counseling management model and validity of guidance and counseling management model based Sumang in Senior High School.

\section{METHOD}

The method in this research is the research development model (Reasearch and Development), aims to produce a model product management guidance and counseling based sumang gayo. Development research is used to describe activities related to creation or new discoveries, methods, products, to meet needs [8].

Stage in research with Research and Development (R \& D) method: research and information collecting, planning, preliminary form of roduct, preliminary field test, main product revision, main field testing, operational product revision, operational field testing, final product revision, dissemination and implementation. The goal is to get the results of this study has a high validity, by testing external validity to the design of guidance and counseling managemet model based on sumang gayo.

This research was conducted at Senior High School (SMAN 10 Takengon). Sources of data to validate the guidance and counseling management model based on sumang gayo are: 3 instructor of guidance and counseling, 3 headmaster, 2 Supervisors, 3 Senior Teachers, 3 management Board of teacher guidance and counseling Aceh Tengah District.

Table 1. Criterion of conformity indicators

\begin{tabular}{|c|c|c|}
\hline score & $\begin{array}{c}\text { Percentage } \\
\text { Intervals }\end{array}$ & Criteria \\
\hline 4 & $90 \% \leq \mathrm{x}<100 \%$ & very appropriate \\
\hline 3 & $80 \% \leq \mathrm{x}<89 \%$ & appropriate \\
\hline 2 & $70 \% \leq \mathrm{x}<79 \%$ & less appropriate \\
\hline 1 & $<69 \%$ & very inappropriate \\
\hline
\end{tabular}

\section{ENDING AND DISCUSSION}

The process of implementing the development of guidance and counseling management model based on sumang gayo is done gradually starting from research and data collection (Research \& Information Collecting) up to product validation. The design of guidance and counseling management model based on sumang gayo consists of four components that govern the behavior interacting in Gayo people. The four components of sumang gayo are : guarding interaction (sumang pelangkahen), guarding the view (sumang penengonen), keep mouth/speech (sumang perceraken), keep attitude (sumang kenunulen). Here is the scheme of integrating sumang gayo values in guidance and counseling management :

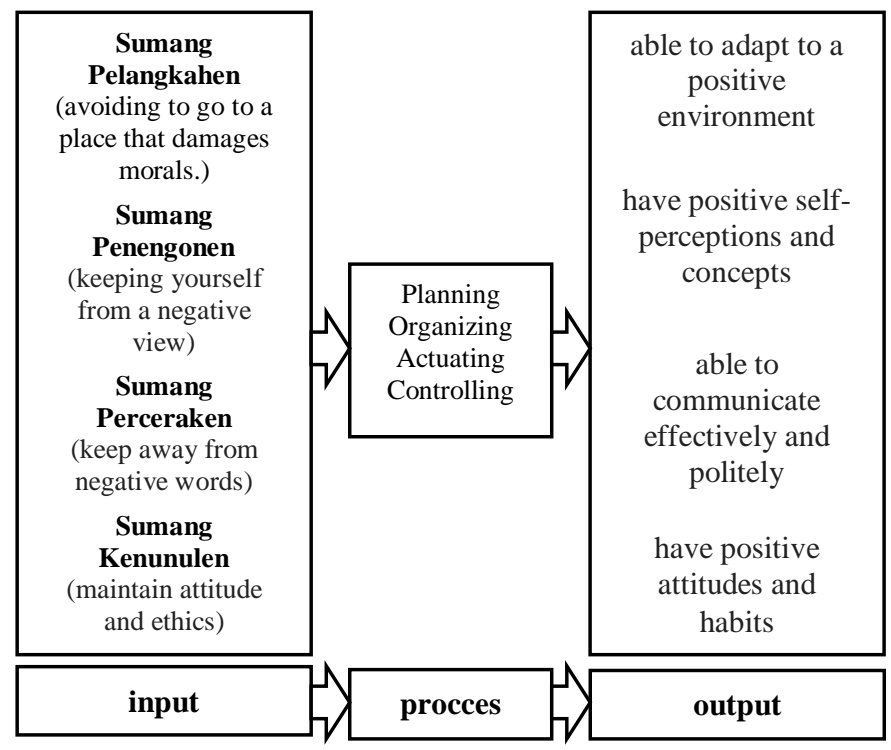

Guidance and counseling management model based on sumang gayo in this research is as follows :

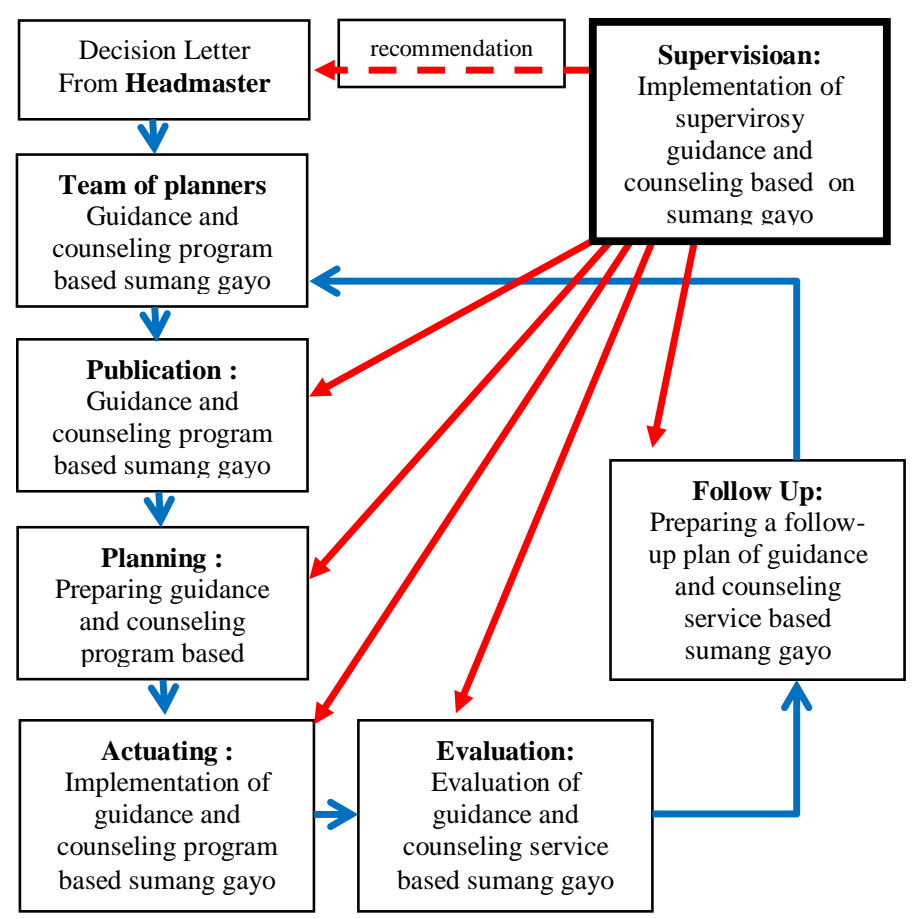


Developing guidance and counseling management model based on sumang gayo in this research is as follows :

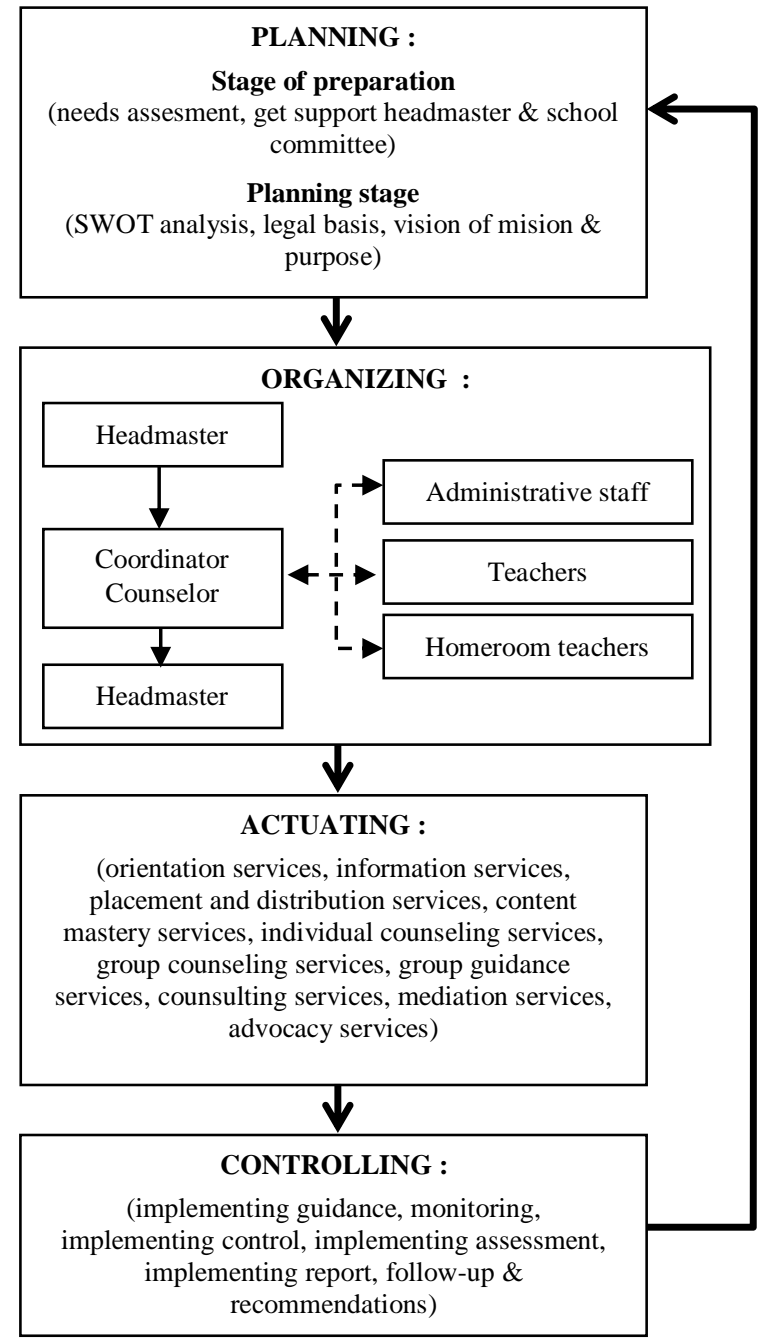

The validity test of guidance and counseling management model based on sumang gayo is conducted by 3 instructors of guidance and counseling, 3 headmasters, 2 supervisors, 3 senior teacher of guidance and counseling, and 3 management Board of teacher guidance and counseling Aceh Tengah District.

Table 2. Assessment 3 Instructor teacher of guidance and counseling

\begin{tabular}{|c|c|c|c|c|c|c|c|}
\hline No & Indicator & R1 & R2 & R3 & Amount & Average & Criteria \\
\hline 1 & Planning & 4 & 4 & 4 & 12 & 4 & very appropriate \\
\hline 2 & Organizing & 4 & 4 & 4 & 12 & 4 & very appropriate \\
\hline 3 & Actuating & 3 & 4 & 4 & 11 & 3.6 & very appropriate \\
\hline 4 & Controlling & 4 & 3 & 3 & 10 & 3.3 & very appropriate \\
\hline \multicolumn{6}{|c|}{ Average total } & 3.7 & \multirow{2}{*}{ very appropriate } \\
\hline \multicolumn{6}{|c|}{ Percentage } & $90 \%$ & \\
\hline
\end{tabular}

From table 2. Assessment instructors to guidance and counseling management model based on sumang gayo as follows :
All instructors $(100 \%)$ stated that the indicators of planning, vision, mission and goals of guidance and counseling based on sumang gayo are very appropriate.

All instructors $(100 \%)$ stated that the organizing indicators of guidance and counseling based on sumang gayo are very appropriate.

Two instructors $(67 \%)$ stated that the implementation indicator of guidance and counseling based on sumang gayo are very appropriate. Then, one instructor $(33 \%)$ stated that the implementation indicator are appropriate.

Two instructors $(67 \%)$ stated that the evaluation indicators of guidance and counseling based on sumang gayo are appropriate. Then, one instructor $(33 \%)$ stated that the evaluation indicator are very appropriate.

Table 3. Assessment 3 Headmasters

\begin{tabular}{|c|c|c|c|c|c|c|c|}
\hline No & Indicator & $\mathrm{R} 1$ & R2 & R3 & Amount & Average & Criteria \\
\hline 1 & Planning & 4 & 4 & 4 & 12 & 4 & very appropriate \\
\hline 2 & Organizing & 4 & 3 & 4 & 11 & 3.6 & very appropriate \\
\hline 3 & Actuating & 3 & 4 & 4 & 11 & 3.6 & very appropriate \\
\hline 4 & Controlling & 4 & 4 & 3 & 11 & 3.6 & very appropriate \\
\hline \multicolumn{6}{|c|}{ Average total } & 3.7 & \multirow{2}{*}{ very appropriate } \\
\hline \multicolumn{6}{|c|}{ Percentage } & $90 \%$ & \\
\hline
\end{tabular}

From table 3. Assessment headmasters to guidance and counseling management model based on sumang gayo as follows :

All headmasters $(100 \%)$ stated that the indicators of planning, vision, mission and goals of guidance and counseling based on sumang gayo are very appropriate.

Two headmasters $(67 \%)$ stated that the organizing indicators of guidance and counseling based on sumang gayo are very appropriate. Then, one headmaster (33\%) stated that the organizing indicator are appropriate.

Two headmasters $(67 \%)$ stated that the implementation indicator of guidance and counseling based on sumang gayo are very appropriate. Then, one headmaster $(33 \%)$ stated that the implementation indicator are appropriate.

Two headmaster $(67 \%)$ stated that the evaluation indicators of guidance and counseling based on sumang gayo are appropriate. Then, one headmaster $(33 \%)$ stated that the evaluation indicator are very appropriate.

Table 4. Assessment 2 Supervisor

\begin{tabular}{|c|c|c|c|c|c|c|}
\hline No & Indicator & $\mathrm{R} 1$ & $\mathrm{R} 2$ & Amount & Average & Criteria \\
\hline 1 & Planning & 4 & 4 & 12 & 4 & very appropriate \\
\hline 2 & Organizing & 4 & 4 & 12 & 4 & very appropriate \\
\hline 3 & Actuating & 4 & 4 & 12 & 4 & very appropriate \\
\hline 4 & Controlling & 4 & 4 & 12 & 4 & very appropriate \\
\hline \multicolumn{5}{|c|}{ Average total } & 4 & \multirow{2}{*}{ very appropriate } \\
\hline \multicolumn{5}{|c|}{ Percentage } & $100 \%$ & \\
\hline
\end{tabular}

From table 4. Assessment supervisor to guidance and counseling management model based on sumang gayo as follows : 
All supervisor (100\%) stated that the indicators of planning, vision, mission and goals of guidance and counseling based on sumang gayo are very appropriate.

All supervisor $(100 \%)$ stated that the organizing indicators of guidance and counseling based on sumang gayo are very appropriate.

All supervisor $(100 \%)$ stated that the implementation indicator of guidance and counseling based on sumang gayo are very appropriate.

All supervisor $(100 \%)$ stated that the evaluation indicators of guidance and counseling based on sumang gayo are very appropriate.

Table 5. Assessment 3 Senior teacher

\begin{tabular}{|c|c|c|c|c|c|c|c|}
\hline No & Indicator & R1 & $\mathrm{R} 2$ & R3 & Amount & Average & Criteria \\
\hline 1 & Planning & 4 & 4 & 4 & 12 & 4 & very appropriate \\
\hline 2 & Organizing & 3 & 4 & 3 & 10 & 3.3 & very appropriate \\
\hline 3 & Actuating & 4 & 4 & 4 & 12 & 4 & very appropriate \\
\hline 4 & Controlling & 4 & 4 & 4 & 12 & 4 & very appropriate \\
\hline \multicolumn{6}{|c|}{ Average total } & 3.8 & \multirow{2}{*}{ very appropriate } \\
\hline \multicolumn{6}{|c|}{ Percentage } & $90 \%$ & \\
\hline
\end{tabular}

From table 5. Assessment senior teacher to guidance and counseling management model based on sumang gayo as follows :

All senior teacher $(100 \%)$ stated that the indicators of planning, vision, mission and goals of guidance and counseling based on sumang gayo are very appropriate.

Two senior teacher $(67 \%)$ stated that the organizing indicators of guidance and counseling based on sumang gayo are appropriate. Then, one senior teacher $(33 \%)$ stated that the organizing indicator are very appropriate.

All senior teacher $(100 \%)$ stated that the implementation indicator of guidance and counseling based on sumang gayo are very appropriate.

All senior teacher (100\%) stated that the evaluation indicators of guidance and counseling based on sumang gayo are very appropriate.

Table 6. Assessment 3 management board of teacher guidance and counseling

\begin{tabular}{|c|c|c|c|c|c|c|c|}
\hline No & Indicator & R1 & R2 & $\mathrm{R} 3$ & Amount & Average & Criteria \\
\hline 1 & Planning & 4 & 4 & 4 & 12 & 4 & very appropriate \\
\hline 2 & Organizing & 4 & 3 & 4 & 11 & 3.6 & very appropriate \\
\hline 3 & Actuating & 4 & 4 & 4 & 12 & 4 & very appropriate \\
\hline 4 & Controlling & 3 & 4 & 4 & 11 & 3.6 & very appropriate \\
\hline \multicolumn{6}{|c|}{ Average total } & 3.8 & \multirow{2}{*}{ very appropriate } \\
\hline \multicolumn{6}{|c|}{ ntage } & $90 \%$ & \\
\hline
\end{tabular}

From table 6. Assessment management board of teacher to guidance and counseling management model based on sumang gayo as follows :

All management board of teacher $(100 \%)$ stated that the indicators of planning, vision, mission and goals of guidance and counseling based on sumang gayo are very appropriate.
Two management board of teacher $(67 \%)$ stated that the organizing indicators of guidance and counseling based on sumang gayo are very appropriate. Then, one management board of teacher $(33 \%)$ stated that the organizing indicator are very appropriate.

All management board of teacher (100\%) stated that the implementation indicator of guidance and counseling based on sumang gayo are very appropriate.

Two management board of teacher $(67 \%)$ stated that the evaluation indicators of guidance and counseling based on sumang gayo are very appropriate. Then, one management board of teacher $(33 \%)$ stated that the evaluation indicator are appropriate.

The result of research and development of guidance and counseling management model based on sumang gayo can be concluded:

1. Guidance and counseling management model based on sumang gayo very feasible in use.

2. Validator guidance and counseling management model based on sumang gayo done by assessment 3 instructor teacher of guidance and counseling are very appropriate, assessment 3 headmasters are very appropriate, assessment 2 supervisors are very appropriate, assessment 3 senior teacher are very appropriate, and assessment 3 management Board of teacher are very appropriate. Indicates that the guidance and counseling management model based on sumang gayo is very feasible to use.

\section{REFERENCE}

[1] Zamroni, Edris. (2014). "Manajemen Bimbingan Dan Konseling Berbasis Permendikbud Nomor 111 Tahun 2014”. Jurnal Konseling GUSJIGANG Vol. 1 No. 1 Tahun 2015 ISSN 2460-1187. (accessed, 25 February 2017).

[2] Aminah, Siti (2014). "Pengembangan Model Program Bimbingan Dan Konseling Berbasis Karakter di Sekolah". http://journal.unnes.ac.id/sju/ index.php/jubk. Jurnal Bimbingan Konseling (accessed, 03 December 2016).

[3] Prayitno dan Belferik Manulang. (2010). "Pendidikan Karakter Dalam Pembangunan Bangsa”. Medan : Pascasarjana Unimed.

[4] Ibrahim, Mahmud. (2010). "Syari'at dan Adat Istiadat". Takengon Barat : Maqamammahmuda.

[5] Lestari, Titit. (2012). "Sumang Dalam Budaya Gayo". Banda Aceh : Balai Pelestarian Sejarah dan Nilai Tradisional.

[6] Al Musanna. (2011). "Rasionalitas dan Aktualitas Kearifan Lokal Sebagai Basis Pendidikan Karakter". Jurnal Pendidikan dan Kebudayaan, Vol. 17, Nomor 6, November 2011 (accessed, 24 March 2017)

[7] Ruhdi Bathin, Win (2012). Budaya Sumng dan Tutur Gayo Mulai Menghilang. Artikel Online. http://atjehpost.co/berita1/read/ BudayaSumang-dan-Tutur-Gayo-Mulai-Menghilang-7961. (accessed, 24 March 2017)

[8] Putra, Nusa. (2015). "Research and Development : Penelitian dan Pengembangan Suatu Pengantar”. Jakarta : Raja Grafindo Persada. 